\title{
Penerapan Enterprise Resource Planning (ERP) Pengadaan Bahan Baku dan Pengelolaan Produksi Pada Perusahaan Furniture Menggunakan ADempiere (Studi Kasus: CV Roland Kencana)
}

\author{
Hasdi P1, Ravi Azhari² \\ 1,2 Program Studi Sistem Informasi Fakultas Teknologi Informasi Universitas Andalas, Padang 25163 INDONESIA
}

hasdiputra@fti.unand.ac.id, ravi.azhari@ymail.com

\begin{abstract}
In this era of global competition, companies need to shorten the production cycle, responsive to market dynamics and customer demand and to strengthen information exchange system. In this competitive environment, Enterprise Resource Planning (ERP) is very helpful in integrating the management of all the company's resources. In manufacturing companies such as furniture, raw materials shall be made available for the production process. Shortages of raw materials can be anticipated early through inventory information that can be accessed quickly and accurately so that the business process is still running. This study aims to assist companies in implementing ERP systems by proposing strategies and tactics to overcome the problems encountered in implementing ERP systems. ADempiere as one ERP applications can help manage the transaction data and inventory business processes to improve corporate performance. The stages are carried out in this research is to identify problems, analyze business processes, election ADempiere application modules, implementation and testing of applications. Business processes are identified consisting of sales, purchasing and production. The results of analysis of business processes described in the Business Process Modeling Notation (BPMN) and a working model of the system is shown by the use case diagram. System test results obtained by comparing the ERP system using the manual system. The test results prove that ADempiere can produce the raw material inventory information in real time, generate transaction reports purchases, sales, production, and financial reports automatically so that it can help company leaders make decisions quickly and accurately.
\end{abstract}

Keywords: ERP Implementation, ADempiere, raw materials, manufacturing

Intisari-Pada era persaingan global ini, perusahaan perlu mempersingkat siklus produksi, responsif terhadap dinamika pasar dan permintaan pelanggan serta memperkuat sistem pertukaran informasi. Dalam lingkungan yang kompetitif ini, Enterprise Resources Planning (ERP) sangat membantu dalam mengintegrasikan pengelolaan seluruh sumber daya perusahaan. Pada perusahaan manufaktur seperti furniture, bahan baku harus senantiasa tersedia untuk proses produksi. Kekurangan bahan baku bisa diantisipasi lebih awal melalui informasi persediaan yang bisa di akses secara cepat dan akurat sehingga proses bisnis tetap berjalan. Penelitian ini bertujuan untuk membantu perusahaan dalam menerapkan sistem ERP dengan mengusulkan strategi dan taktik untuk mengatasi masalah yang dihadapi dalam menerapkan sistem ERP. ADempiere sebagai salah satu aplikasi ERP dapat membantu mengelola data transaksi dan inventory dalam proses bisnis untuk meningkatkan kinerja perusahaan. Tahapan-tahapan yang dilakukan dalam penelitian ini adalah identifikasi masalah, menganalisis proses bisnis, pemilihan modul aplikasi ADempiere, implementasi dan pengujian aplikasi. Proses bisnis yang diidentifikasi adalah penjualan, pembelian dan produksi. Hasil analisis proses bisnis digambarkan dengan Business Process Modeling Notation (BPMN) dan model kerja sistem ditunjukkan dengan use case diagram. Hasil pengujian sistem didapatkan dengan membandingkan sistem yang menggunakan ERP dengan sistem manual. Hasil pengujian membuktikan bahwa ADempiere dapat menghasilkan informasi persediaan bahan baku secara realtime, menghasilkan laporan transaksi pembelian, penjualan, produksi, dan laporan keuangan secara otomatis sehingga dapat membantu pimpinan perusahaan dalam mengambil keputusan dengan cepat dan tepat.

Kata kunci: Penerapan ERP, ADempiere, persediaan bahan baku, pengelolaan produksi

\section{Pendahuluan}

CV Roland Kencana merupakan perusahaan industri manufaktur di bidang furniture. Perusahaan furniture ini memproduksi perlengkapan dapur (kitchen set), perlengkapan kamar seperti lemari dan full set tempat tidur atau produk sesuai dengan permintaan pelanggan. Sistem yang diterapkan perusahaan dalam pengerjaan produknya adalah make to order yaitu memproduksi barang jika ada pesanan dari pelanggan. Sebagai UKM (Usaha Kecil Menengah) perusahaan harus mampu mempertahankan produktifitas dan kualitasnya, sehingga menuntut perusahaan untuk selalu 
meningkatkan performansi serta meminimalisir kerugian-kerugian berupa gagal produksi, kesulitan mengetahui kebutuhan bahan baku, kesulitan dalam menyusun dokumentasi dan laporan, juga bertambahnya target pencapaian dari perusahaan sendiri. Lambatnya perusahaan dalam menerima informasi persediaan bahan baku, menyebabkan perencanaan dan proses produksi menjadi tertunda. Perencanaan produksi meliputi, kebutuhan bahan baku, tenaga kerja serta waktu yang digunakan dalam memenuhi permintaan. Pada perusahaan belum tersedianya orders report, info persediaan bahan baku untuk kebutuhan produksi, laporan produksi, dan laporan keuangan yang kurang jelas. Pemesanan tercatat pada satu proses tanpa adanya daftar pesanan yang menampilkan waktu pemesanan. Hal ini menyebabkan direktur perusahaan lambat mengambil keputusan. Lambatnya informasi yang tersedia, dan masing masing divisi yang tidak terintegrasi sehingga mebutuhkan waktu yang lama dalam pengumpulan data.

Sebagai industri manufaktur, CV Roland Kencana perlu mengelola persediaan bahan baku dan produksi secara efektif dan efisien. Perusahaan perlu memiliki sistem komputerisasi yang terintegfrasi untuk mendukung proses bisnis dan saling terintegrasi sehingga dapat membantu pengambilan keputusan dengan tepat. ERP (Enterprise Resource Planning) merupakan solusi yang tepat untuk mengatasi permasalahan tersebut. Dengan sistem ERP, perusahaan dapat mengintegrasikan dan meningkatkan efesiensi proses bisnis [1]. ERP merupakan sistem berbasis komputer yang didesain untuk proses transaksi organisasi dan fasilitas yang terintegrasi serta perencanaan yang real-time, produksi, dan respon pelanggan [2]. Penerapan sistem ERP ke dalam perusahaan merupakan salah satu strategi yang banyak digunakan oleh perusahaan untuk meningkatkan kualitas sistem informasinya. Hal ini dikarenakan ERP merupakan bagian dari infrastruktur perusahaan yang dapat menunjang kelancaran proses bisnis perusahaan yang menerapkannya [3].

Aplikasi ADempiere merupakan salah satu aplikasi Enterprise Resource Planning (ERP) yang dapat membantu dalam mengelola data pada perusahaan seperti data transaksi dan data produksi [4]. Aplikasi ADempiere merupakan salah satu aplikasi dalam bidang Enterprise Resource Planning (ERP) yang dapat membantu dalam mengelola data dalam proses bisnis di suatu perusahaan seperti data transaksi dan inventory. Terlebih aplikasi ADempiere ini merupakan aplikasi tidak berbayar atau open source dan dapat dikustom sesuai dengan proses bisnis perusahaan yang akan digunakan dan sistem yang saling terintegrasi [5]. Dengan adanya ADempiere, pencatatan akan lebih akurat dan lebih cepat dibandingkan pencatatan yang masih manual, sehingga dapat meminimalkan kesalahan pencatatan, pemesanan produk, persediaan bahan baku, pengelolaan gudang, laporan produksi, dan laporan keuangan.

Penerapan Enterprise Resource Planning (ERP) menggunakan ADempiere telah dilakukan pada PT. Global Agrotek Nusantara (GAN). Dari hasil penelitiannya, pemakaian modul Quote to Invoice, Request to Invoice, Material Management, Performance Analysis, dan Manufacturing Management menunjukkan modul yang saling terkait satu sama lain dalam memperoleh data sehingga menghasilkan sebuah laporan keuangan sesuai dengan kebutuhan perusahaan [6]. Sedangkan implementasi ERP menggunakan ADempiere pada PT. X berfokus pada bagian produksi. Dengan hasil penelitiannya, ADempiere dapat digunakan dalam mengelola bahan baku untuk proses produksi [7].

\section{TinjauAn PUStaka}

\section{A. Proses Produksi}

Proses produksi adalah suatu cara, metode ataupun teknik menambah keguanaan suatu barang dan jasa dengan menggunakan faktor produksi yang ada [8].

\section{B. Persediaan Bahan Baku}

Pengendalian persedian merupakan fungsi manajerial yang sangat penting karena persediaan fisik banyak melibatkan investasi rupiah terbesar. Bila perusahaan menamankan terlalu banyak dananya dalam persediaan, menyebabkan biaya penyimpanan yang berlebihan, dan mungkin mempunyai “opportunity cost" (dana dapat ditanamkan dalam investasi yang lebih menguntungkan". Sebaliknya, bila perusahaan tidak mempunyai persediaan yang cukup dapat mengakibatkan biaya-biaya karena kekurangan bahan [9].

\section{Enterprise Resource Planning (ERP)}

Enterprise Resource Planning (ERP) system adalah sistem berbasis komputer yang didesain untuk proses transaksi organisasi dan fasilitas yang terintegrasi serta perencanaan yang real-time, produksi, dan respon pelanggan [2].

\section{ADempiere}

ADempiere merupakan aplikasi ERP berbasis opensource yang merupakan turunan dari Compiere ERP dan CRM. Adempiere memiliki hampir semua keistimewaan yang dimiliki oleh Compiere di tambah modul - modul yang dikembangkan seperti modul Manufacturing, HR, POS, dll. Adempiere dibangun menggunakan Java J2EE dapat dijalankan di berbagai platfrom seperti Windows, Linux, Unix dan lain-lain. ADempiere juga terintegrasi dengan semua data (ERP, CRM dan Accounting) sehingga tidak diperlukan migrasi atau penggabungan data dan Adempiere juga memiliki Smart User Interface yang sangat user friendly yang kaya akan fitur [4]. 


\section{E. Business Process Model and Process (BPMN)}

BPMN adalah suatu metodologi baru yang dikembangkan oleh Business Process Modeling Initiative sebagai suatu standar baru pada pemodelan proses bisnis, dan juga sebagai alat desain pada sistem yang kompleks seperti sistem eBusiness yang berbasis pesan (message-based) [10].

\section{F. Use Case Diagram}

Use case diagram adalah diagram yang membantu dalam menyusun requirement sebuah sistem, mengkomunikasikan rancangan dengan klien, dan merancang test case untuk semua fitur yang ada pada sistem. Use case diagram menggunakan fungsionalitas yang diharapkan dari sebuah sistem. Use case diagram menekankan apa yang dibuat sistem, dan bukan bagaimana. Sebuah use case merepresentasikan sebuah interaksi antara actor dan sistem [11].

\section{Metode Penelitian}

Metode penelitian digambarkan dalam bentuk flowchart yang dapat dilihat pada Gambar 1.

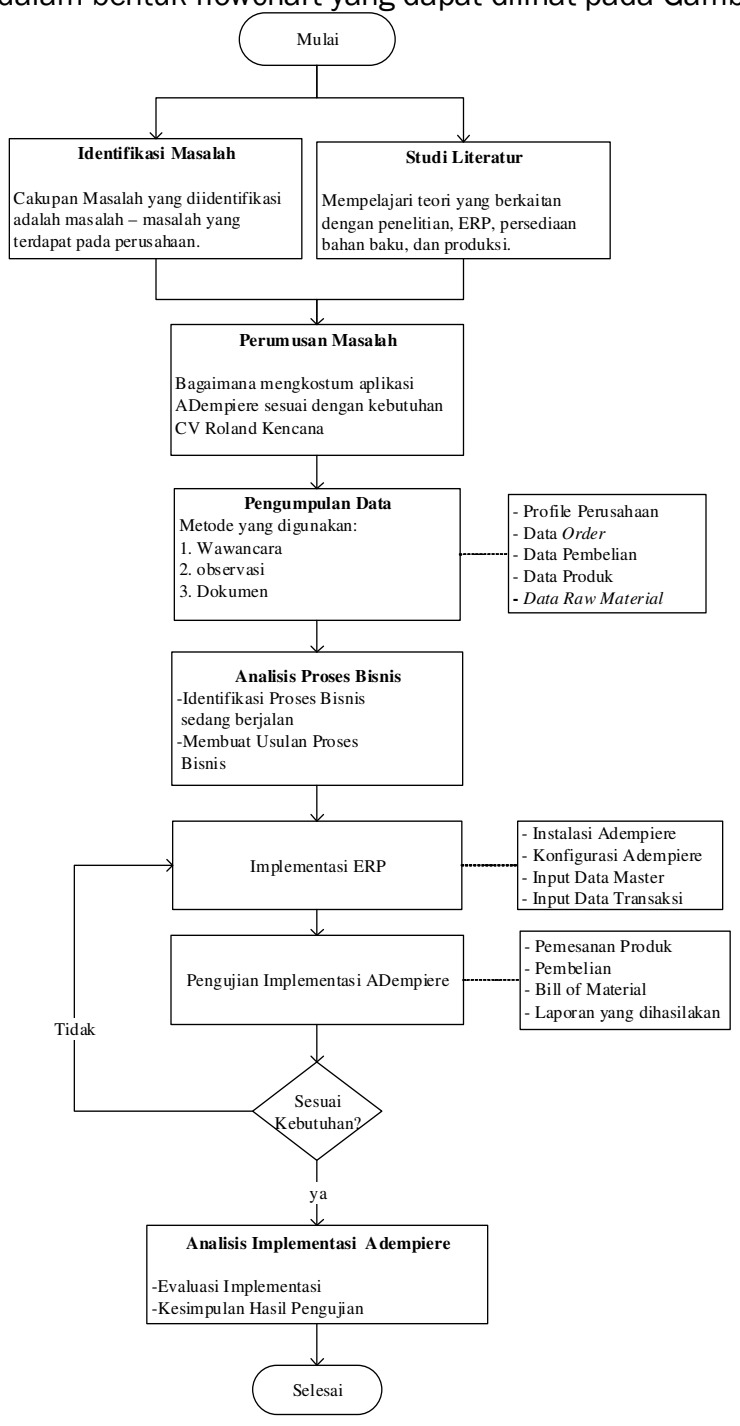

Gambar 1. Flowchart Metode Penelitian 


\section{A. Identifikasi Masalah}

Permasalah yang diidentifikasi adalah masalah-masalah yang terdapat di perusahaan khususnya pada bagian persediaan bahan baku dan produksi.

\section{B. Studi Literatur}

Studi literatur digunakan untuk mencari landasan teori dan penelitian yang terkait dengan objek yang diteliti yaitu mengenai penerepan sistem ERP.

C. Pengumpulan Data

Beberapa metode pengumpulan data yang dilakukan dalam penelitian ini:

1) Wawancara. Melakukan wawancara mengenai proses pembelian bahan baku, produksi dan penyusunan laporan keuangan.

2) Observasi. Melakukan pengamatan langsung terhadap proses pembelian bahan baku, penerimaan bahan baku proses produksi. Pengamatan dilakukan terhadap proses, dokumen dan orang yang terlibat dalam proses tersebut.

3) Dokumen. Meminta dokumen yang berhubungan dengan proses pembelian bahan baku dan produksi.

\section{Perumusan Masalah}

Tahapan ini merupakan kelanjutan dari proses identifikasi masalah dengan menggunakan studi literatur untuk merumuskan permasalahan.

\section{E. Analisis Proses Bisnis}

Analisis Proses Bisnis dilakukan dengan mengidentifikasi proses bisnis perusahaan kemudian membuat usulan sistem untuk mengimplementasikan ERP. Proses bisnis digambarkan dengan menggunakan Business Process Modelling Notation (BPMN). Sedangkan use case diagram digunakan untuk menggambarkan kinerja sistem. Proses bisnis yang diidentifikasi adalah proses bisnis pembelian bahan baku, proses bisnis produksi, dan proses bisnis pemesanan produk.

F. Implementasi ADempiere

Tahapan implementasi ADempiere adalah instalasi, konfigurasi, input data master, dan input transaksi.

\section{G. Pengujian Aplikasi ADempiere}

Pengujian ADempiere dilakukan untuk melihat kesesuaian penerapan aplikasi ADempiere pada proses bisnis. Proses pengujian pada proses bisinis meliputi proses bisnis pembelian bahan baku, produksi, pemesanan produk jadi, dan informasi persedian bahan baku. Pengujian juga dilakukan dengan laporan yang dapat dihasilkan aplikasi ADempiere. Laporan yang dihasilkan adalah laporan pembelian bahan baku, laporan penerimaan barang, laporan produksi, laporan bill of material, laporan penjualan, laporan pengiriman barang, dan laporan keuangan.

H. Hasil Pengujian ADempiere

Menjelaskan tentang hasil evaluasi dan kesimpulan dari penerapan dan pengujian ADempiere.

\section{ANALISIS PRoses Bisnis}

Analisis proses bisnis yang dilakukan adalah proses bisnis yang berkaitan dengan penelitian yaitu pembelian bahan baku, memproses order pelanggan dan proses produksi secara umum. Analisis proses bisnis berguna untuk membantu dalam implementasi aplikasi ADempiere, serta pemilihan modul yang saling terintegrasi.

A. Proses Bisnis yang sedang berjalan

Berikut adalah proses produksi yang sedang berjalan:

1) Bagian produksi menerima order produksi.

2) Bagian produksi membuat perencanaan produksi.

3) Bagian produksi membuat daftar kebutuhan bahan baku.

4) Bagian logistik Menerima daftar bahan baku.

5) Bagian logistik menerima daftar bahan baku.

6) Bagian produksi meminta status stok bahan baku ke bagian gudang.

7) Bagian gudang mengecek persediaan.

8) Bagian gudang memberikan informasi persediaan bahan baku ke bagian logistik.

9) Bagian logistik mengevaluasi persediaan.

10) Jika tersedia makan mengintruksi bagian gudang memindahakan bahan baku ke bagian produksi.

11) Jika tidak maka dilakukan proses pembelian dan proses selesai.

12) Bagian produksi menerima bahan baku.

13) Bagian produksi melakukan proses produksi (pembuatan rangka, pembuatan komponen, pembuatan sambungan, penyetelan, pemasangan asesoris, finishing).

14) Jika produk yang diproduksi ada proses pemasangan asesoris maka dilakukan proses pemasangan, kemudian dilanjutkan dengan proses finishing.

15) Jika produk yang diproduksi tidak ada proses pemasangan asesoris dilanjutkan dengan proses finishing. 
16) Bagian produksi melakukan pengecekan produk.

17) Produk telah selesai diproduksi.

18) Bagian produksi memindahkan barang ke gudang.

19) Bagian gudang menerima produk dan proses selesai.

Proses produksi yang sedang berjalan digambarkan menggunakan BPMN (Business Process Model Notation) seperti pada Gambar 2. Sedangan proses bisnis pembelian bahan baku dan proses pemesan produk atau penjualan yang sedang berjalan diperlihatkan pada Gambar 3 dan Gambar 4.

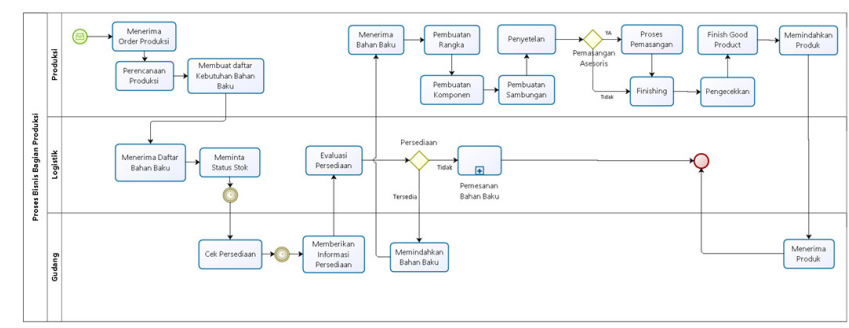

Gambar 2. Proses Produksi yang Sedang Berjalan.

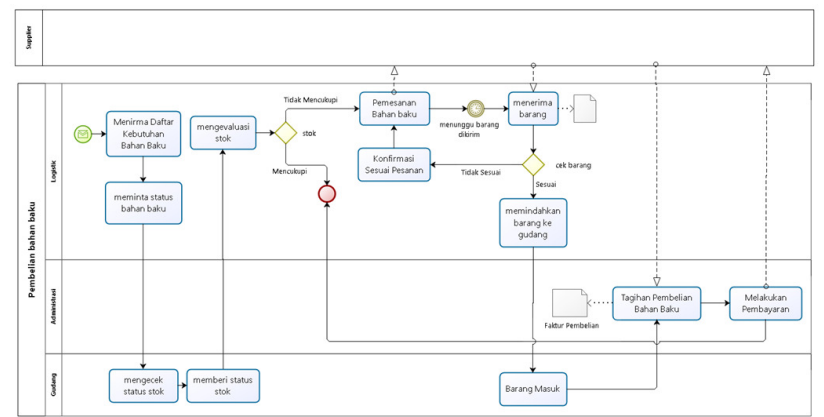

Gambar 3. Proses Pembelian Bahan Baku Sedang Berjalan

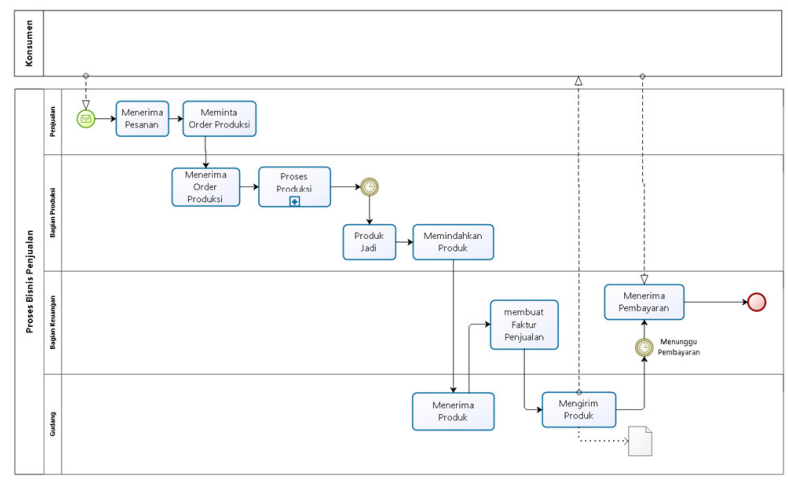

Gambar 4. Proses Pemesanan Produk Sedang Berjalan

B. Proses Bisnis yang diusulkan

Berikut adalah proses produksi yang diusulkan:

1) Bagian produksi menerima order produksi.

2) Bagian produksi input bill of material ke aplikasi.

3) Bagian produksi input manufacturing order ke aplikasi.

4) Bagian logistik melihat component check di aplikasi.

5) Bagian logistik mengevaluasi persediaan. 
6) Jika tersedia makan mengintruksi bagian gudang memindahakan bahan baku ke bagian produksi.

7) Jika tidak maka dilakukan proses pembelian dan proses selesai.

8) Bagian produksi menerima bahan baku.

9) Bagian produksi melakukan proses produksi (pembuatan rangka, pembuatan komponen, pembuatan sambungan, penyetelan, pemasangan asesoris, finishing).

10) Jika produk yang diproduksi ada proses pemasangan asesoris maka dilakukan proses pemasangan, kemudian dilanjutkan dengan proses finishing.

11) Jika produk yang diproduksi tidak ada proses pemasangan asesoris dilanjutkan dengan proses finishing.

12) Bagian produksi melakukan pengecekan produk.

13) Produk telah selesai diproduksi.

14) Bagian produksi input receipt \& issue ke aplikasi.

15) Bagian produksi memindahkan barang ke gudang.

16) Bagian gudang menerima produk dan proses selesai.

Proses produksi yang sedang berjalan digambarkan menggunakan BPMN seperti Gambar 5. Sedangkan proses pembelian bahan baku dan proses penjualan diperlihatkan pada Gambar 6 dan Gambar 7 .

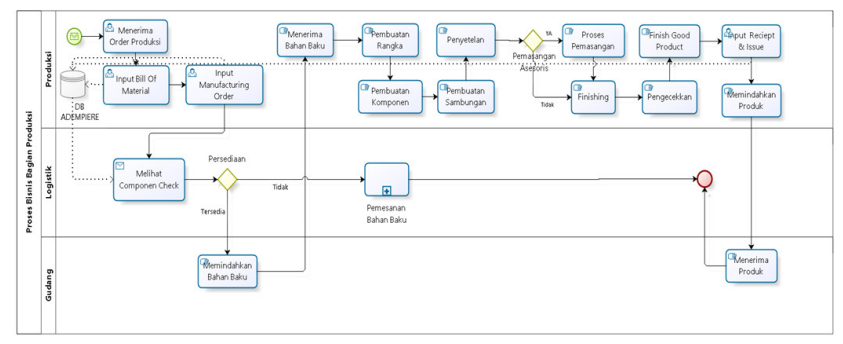

Gambar 5. Proses Produksi yang diusulkan.

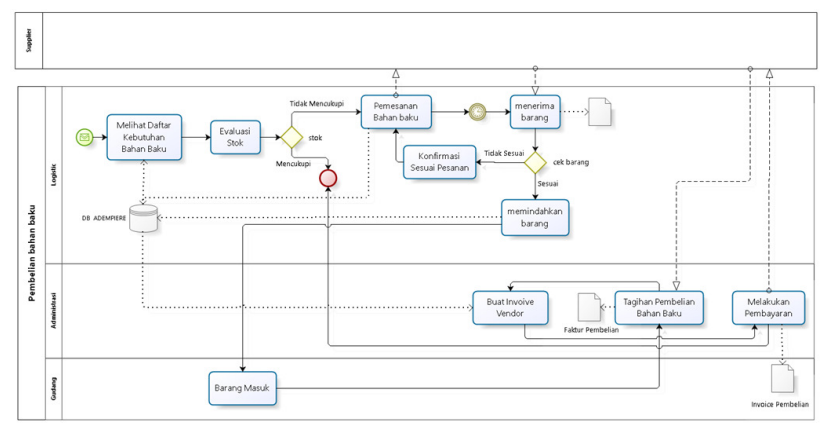

Gambar 6. Proses Pembelian bahan baku yang diusulkan.

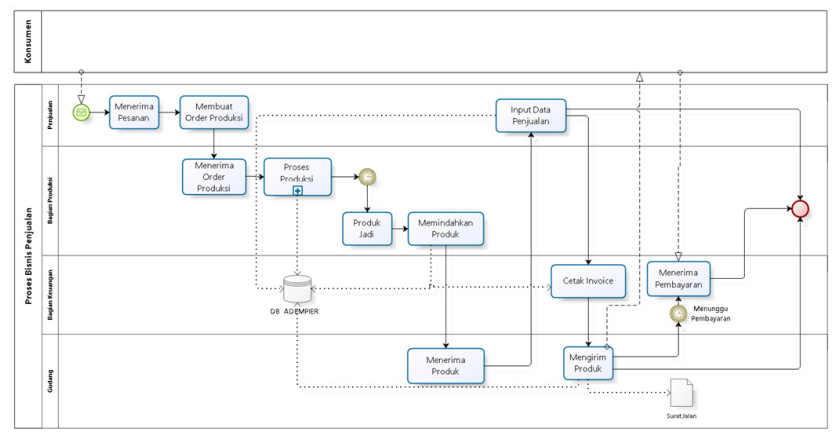

Gambar 7. Proses Pemesanan Produk yang diusulkan 


\section{Use Case Diagram}

Use case diagram digunakan untuk menggambarkan model kerja sistem pada aplikasi. Gambar 8 menunjukkan use case diagram.

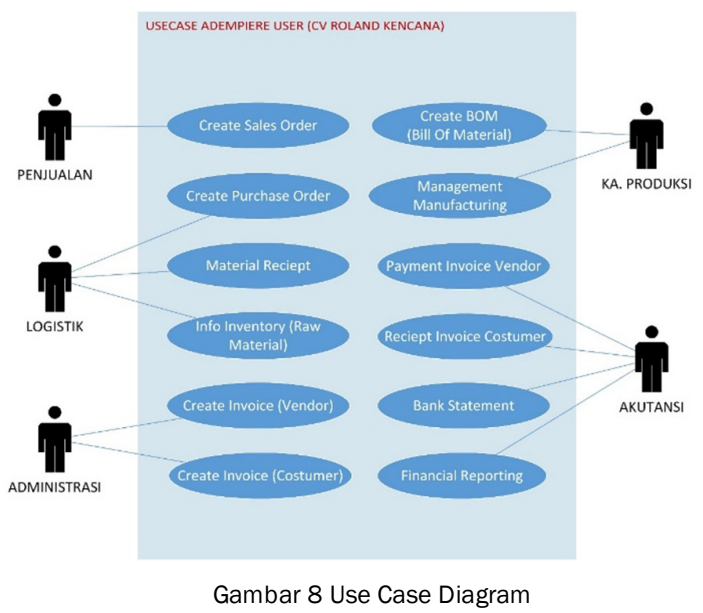

A. Implementasi Sistem

V. IMPLEMENTASI DAN PENGUJIAN

Implementasi aplikasi ADempiere dilakukan berdasarkan proses bisnis yang diusulkan dan metode kerja aplikasi.

1) Konfigurasi client. Konfigurasi client merupakan langkah pertama yang harus dilakukan untuk membuat client baru dan admin perusahaan pada aplikasi. Gambar 9a menunjukkan tampilan form konfigurasi client.

2) Product setup. Gambar 9b menunjukkan workflow setup product.

3) Setup Business Partner. Setup Business Partner bertujuan untuk membuat data konsumen dan data suplier. Untuk mempermudah membuat business partner, ADempiere menyediakan workflow untuk mengurutkan aliran kerja business partner setup. Gambar 9c menunjukkan workflow business partner setup.

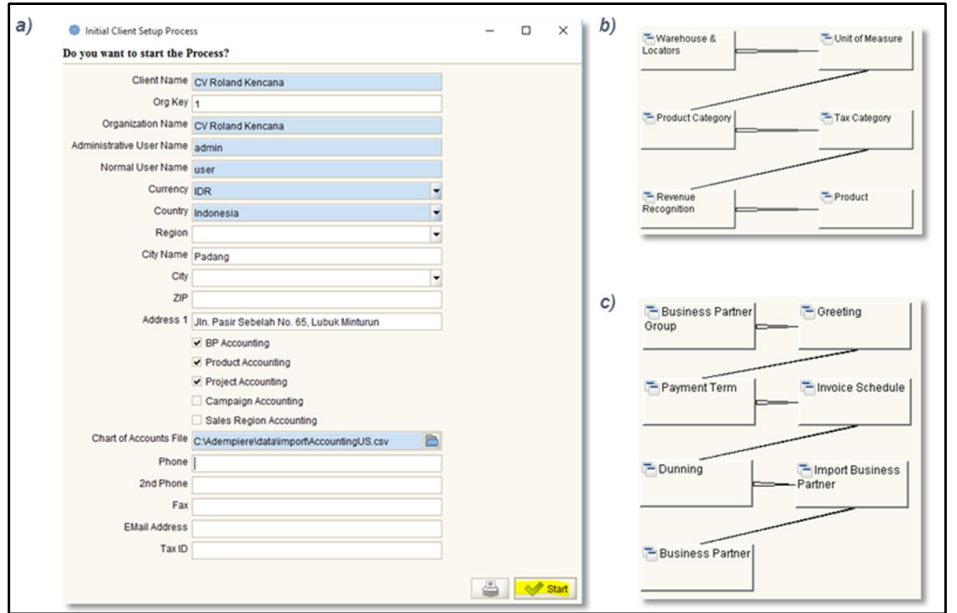

Gambar 9. Penerapan. a) Form Initial Client setup, b) Workflow Setup Product c. Workflow Business Partner Setup

\section{4) Proses Transaksi}

Setelah proses instalasi aplikasi ADempiere dilakukan, konfigurasi, dan input data master selesai, penerapan aplikasi telah bisa dilakukan.

a. Pemesanan Produk

Berikut adalah langkah - langkah dalam proses pemesanan produk oleh pelanggan.

1) Sales order 
Sales Order memproses pesanan pelanggan sehingga menjadi acuan dalam melakukan produksi. Berikut merupakan langkah - langkah membuat sales order:

a) Pada menu awal, klik Quote - to - Invoice > Sales Order > Sales Order, kemudian akan tampil form seperti Gambar 10a. Pada form sales order, pilih business partner (costumer)

b) Selanjutnya, pilih tab Order Line untuk memasukkan produk dan jumlah produk yang dipesan oleh pelanggan. Gambar 10b. menunjukkan form order line.

c) Kemudian kembali ke tab sales order, klik status menjadi prepare untuk pesanan yang belum diproses (belum di fakturkan) atau complete pesanan akan diproses (akan di faktur). Gambar 10 menunjukkan status dari dokumen sales order.

s)

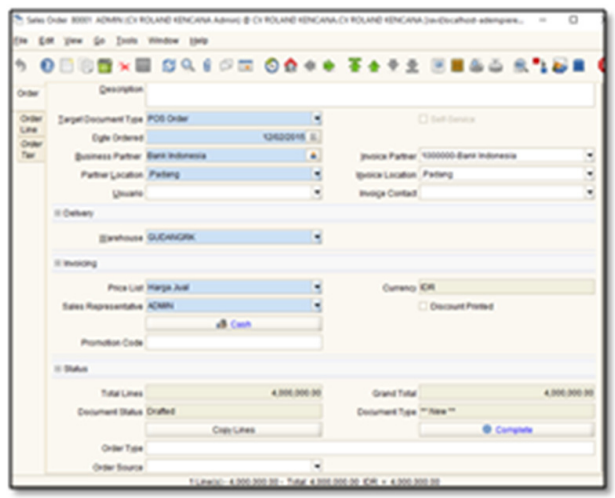

b)

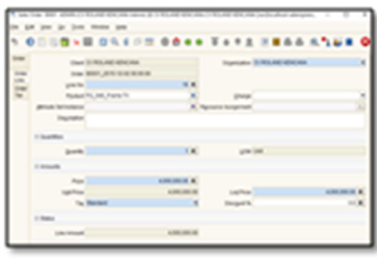

c)

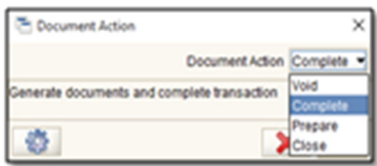

Gambar 10. Sales Order. a) Form Sales Order. b). Form Order Line c). Status Document Sales Order

b. Purchase Order

Berikut adalah langkah - langkah dalam proses pembelian bahan baku.

1) Pada menu awal, klik Requisition -to-invoice > Requisition, maka akan tampil seperti pada Gambar 11.

2) Membuka tab Requisition Line, kemudian akan tampil form seperti Gambar 12. Pada form, inputkan nama business partner dan product.

3) Kembali ke tab requisition dan klik complete, kemudian klik not posted untuk posting jurnal. Pada menu Requisition -to-invoice pilih create PO from Requisition akan tampil form seperti Gambar 11. Pilih requisition yang ingin dijadikan purchase oder kemudian pilih tanggal dokumen, kemudian klik start.

a)

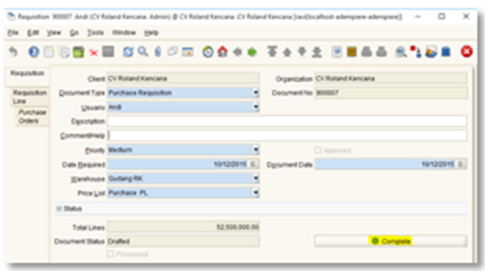

b)

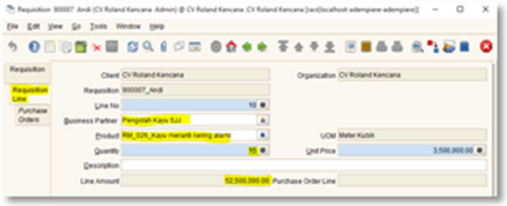

c)

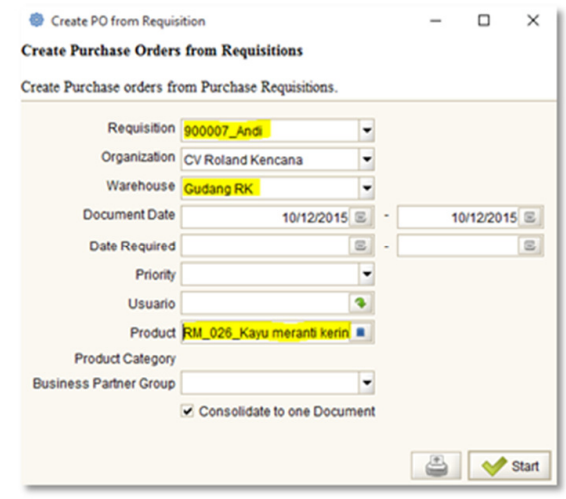

Gambar 11. a) Form Requisition. b) Form Requisition Line. c) Create Purchase From Purchase Requisition.

c. Production

Berikut adalah langkah - langkah dalam proses produksi.

1) Bill Of Material (BOM). BOM adalah komponen - komponen yang digunakan untuk membuat produk jadi. BOM meliputi, Bahan Baku. BOM adalah langkah pertama yang dilakukan untuk membuat sebuah produk. Berikut adalah langkah mendefenisikan BOM. Pada menu awal, klik Material Management > Material Management Rule > Product. Pada form product kemudian pilih tab BOM, kemudian tampil form seperti Gambar 12a. 
2) Manufacturing Workflow Setup. Manufacturing Workflow merupakan alur kerja dan aktivitas dari produksi. Manufacturing Workfow Setup meliputi Resource Type, Manufacturing Resource, Manufacturing Workflows. Gambar 12b menunjukkan alur dari Manufacturing Workfow Setup.

3) Manufacturing Order. Manufacturing Order bertujuan untuk keperluan order produksi pada bagian produksi berdasarkan jadwal yang telah ditetapkan. Untuk bisa memproses manufacturing order, resource type dan manufacturing workflows harus di-input kan terlebih dahulu. Berikut merupakan langkah - langkah proses input Manufacturing Order. Klik Manufacturing Order yang ada pada workflow, kemudian akan tampil form seperti Gambar 12c.

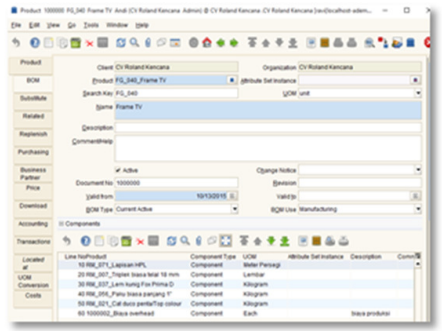

a)

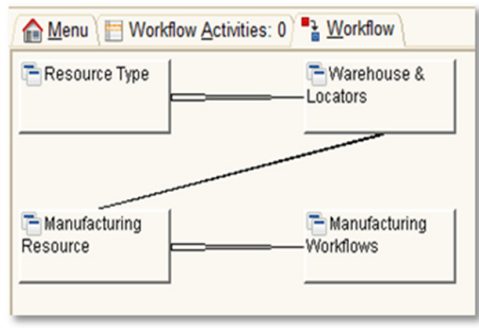

b)

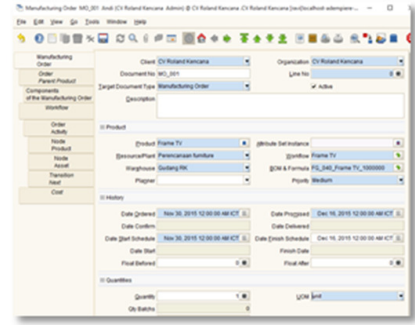

c)

Gambar 12 Produksi a). Form BOM b). Workflow Manufacturing Workflow Setup c). Form Manufacturing Order

B. Pengujian

Pengujian implementasi dilakukan menyesuaikan faktur yang dihasilkan aplikasi ADempiere dengan faktur yang dihasilkan dengan manual.

1) Faktur Pembelian dan Faktur Penjualan

Pada Gambar 13 menunjukkan faktur yang dihasilkan dari supplier dan faktur yang dihasilkan oleh aplikasi ADempiere. Pada Gambar 14 menampilkan faktur penjualan yang dihasilkan aplikasi ADempiere.
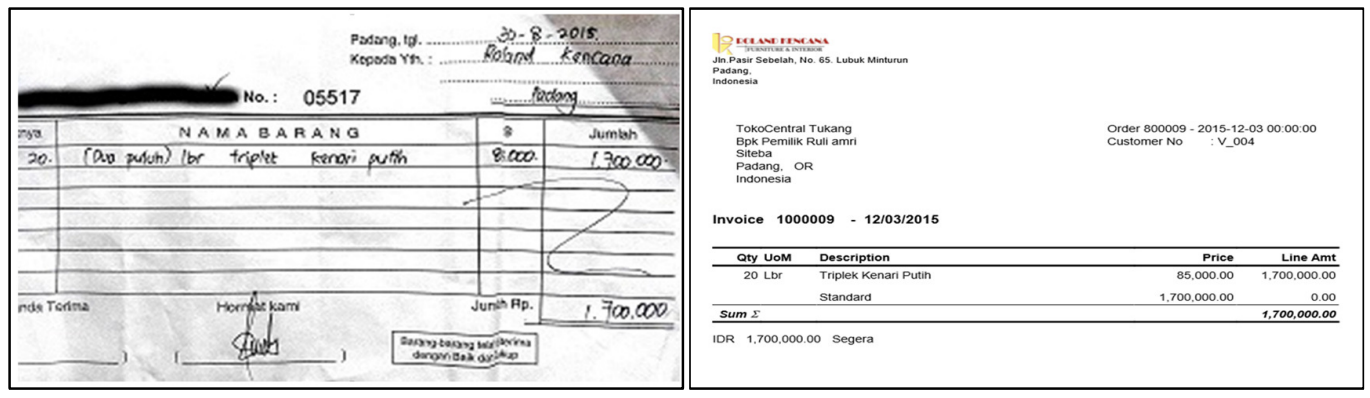

Gambar 13. Faktur Pembelian Bahan Baku (Manual) dan Faktur Pembelian Bahan Baku (ADempiere)

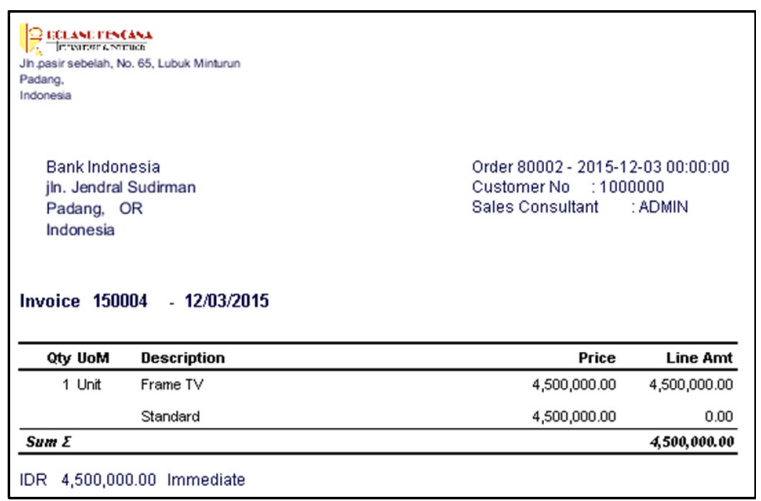

Gambar 14. Faktur Penjualan yang dihasilkan Aplikasi ADempiere 


\section{2) Laporan Produksi}

Laporan produksi yang dihasilkan berupa kebutuhan bahan baku untuk produksi produk, component check, dan laporan produksi yang sedang berjalan. Laporan produksi sangat bermanfaat untuk melihat status produksi pada lantai produksi dan penjadwalan produksi yang telah ditentukan pada saat konsumen memesanan produk. Pada Gambar 15a menampilkan laporan kebutuhan bahan buku untuk produksi produk. Sedangkan Gambar 15b menampilakn laporan component check

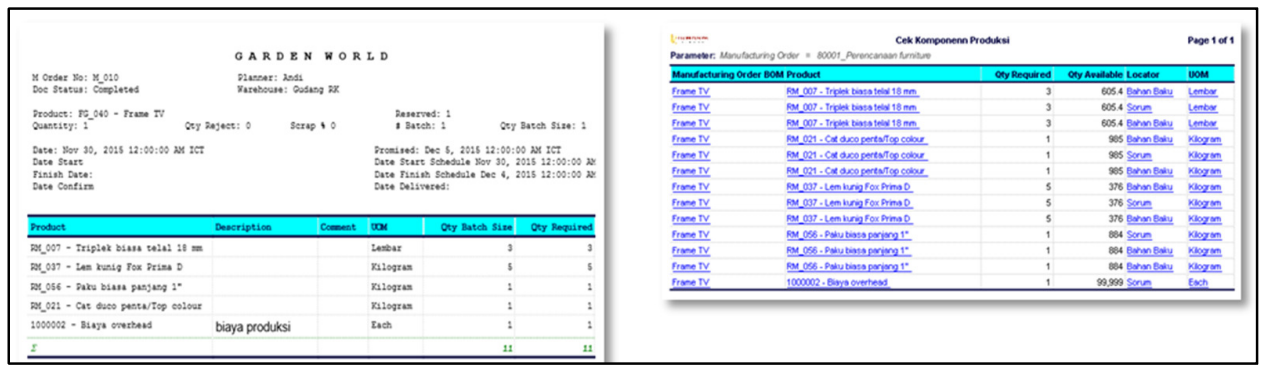

Gambar 15 Laporan Produksi a). kebutuhan bahan buku b). laporan component check

\section{3) Laporan Keuangan}

Laporan keuangan yang dihasilkan adalah neraca dan laba rugi seperti pada Gambar 16 dan Gambar 17 menampilkan laporan laba rugi.

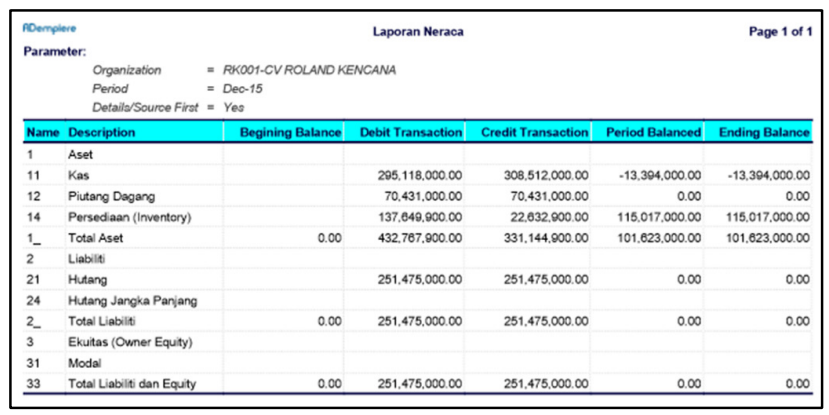

Gambar 164. Laporan Neraca

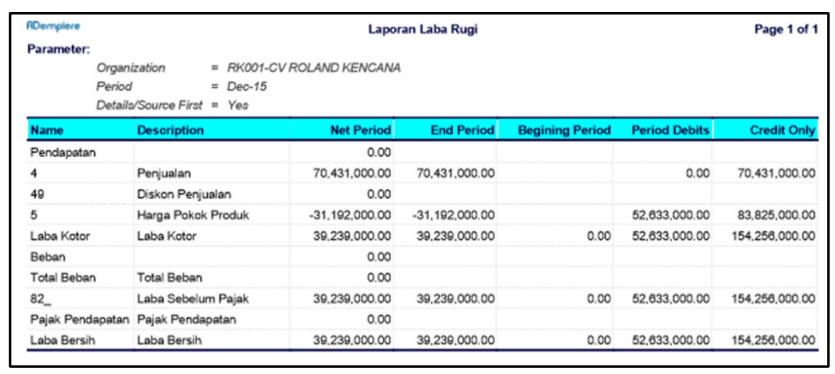

Gambar 175 Laporan Laba Rugi

\section{Hasil Pengujian}

Setelah mengkostum aplikasi ADempiere sesuai dengan proses bisnis CV Roland Kencana, maka dapat disimpulkan bahwa penerapan aplikasi ADempiere dapat mengatasi permasalah dari CV Roland Kencana, dalam penanganan persediaan bahan baku berdasarkan oder dari pelanggan, sehingga membantu dalam perancanaan dan proses produksi. Keberhasilan implementasi aplikasi ADempiere terlihat pada aliran informasi yang real time dan saling terintegrasi. ADempiere dapat menghasilkan laporan keuangan dalam setiap periode. Informasi tersimpan pada satu database sehingga informasi yang dibutuhkan ditampilkan secara real time dan membantu direktur dan manejer dalam fungsi pengawasan serta mengambil keputusan yang tepat dalam menjalankan visi perusahaan. Dari proses penerapan ERP menggunakan ADempiere maka didapatkan perbedaan proses sebelum dan sesudah implementasi ERP menggunakan ADempiere yang ditunjukkan pada Tabel I. Dari Tabel 1 dapat disimpulkan bahwa implementasi ADempiere dapat 
membuat kegiatan proses bisnis menjadi efektif, dikarenakan setiap kegiatan mempunyai laporan dan informasi persedian bahan baku yang bisa diakses secara realtime sehingga dapat meminialisir waktu dalam perencanaan produksi suatu produk. Proses bisnis yang diusulkan dapat mengurangi aktivitas pekerjaan perusahaan. Bagian logistik tidak perlu lagi meminta bagian gudang untuk memeriksa persediaan bahan baku, karena persediaan baku bisa diakses secara realtime dengan menggunakan aplikasi ADempiere. Tabel 1 menunjukkan perbedaan jumlah aktivitas pekerjaan proses bisnis pembelian bahan baku sebelum dan sesudah implementasi ERP menggunakan ADempiere.

TABEL I.

PERBEDAAN PROSES SEBELUM DAN SESUDAH IMPLEMENTASI ERP

\begin{tabular}{|l|c|c|c|c|}
\hline \multirow{2}{*}{ Kegiatan } & \multicolumn{2}{c|}{ Sebelum } & \multicolumn{2}{c|}{ Sesudah } \\
\cline { 2 - 6 } & Proses & Laporan & Proses & Laporan \\
\hline Purchase Order & $\checkmark$ & - & $\checkmark$ & $\checkmark$ \\
\hline Sale Order & $\checkmark$ & - & $\checkmark$ & $\checkmark$ \\
\hline Material Reciept & $\checkmark$ & - & $\checkmark$ & $\checkmark$ \\
\hline Cek persediaan bahan baku & $\checkmark$ & - & $\checkmark$ & $\checkmark$ \\
\hline $\begin{array}{l}\text { Perencanaan Kebutuhan bahan } \\
\text { baku setiap kali produksi }\end{array}$ & $\checkmark$ & - & $\checkmark$ & $\checkmark$ \\
\hline proses produksi & $\checkmark$ & - & $\checkmark$ & $\checkmark$ \\
\hline $\begin{array}{l}\text { Info produk / persediaan bahan } \\
\text { baku }\end{array}$ & - & - & $\checkmark$ & $\checkmark$ \\
\hline Laporan Keuangan & - & - & $\checkmark$ & $\checkmark$ \\
\hline Keterangan: $\checkmark$ Ada -= Tidak & & & \\
\hline
\end{tabular}

Gambar 18 menunjukkan bahwa aktivitas pembelian bahan baku setelah melakukan implementasi lebih sedikit dibandingkan sebelum dilakukannya implementasi ERP. Berdasarkan hasil dari analisis aktivitas pekerjaan tersebut dibuktikan bahwa implementasi ERP dapat meningkatkan efesiensi pekerjaan perusahaan.

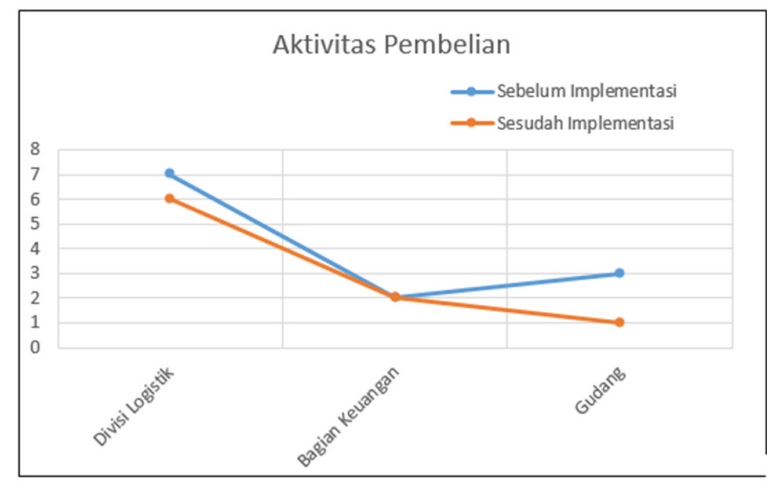

Gambar 18. Grafik Jumlah Aktivitas Pembelian Bahan Baku

\section{KESIMPULAN}

Berdasarkan dari implementasi ADempiere pada CV Roland Kencana yang dimulai dari proses identifikasi masalah, analisis proses bisnis, implementasi dan pengujian aplikasi dapat diambil kesimpulan sebagai berikut:

1. Penerapan Enterprise Resource Planning (ERP) dapat diterapkan pada proses bisnis di CV Roland Kencana diantaranya, pemesanan produk, pembelian bahan baku, persediaan bahan baku dan produksi.

2. Pengujian Implementasi ADempiere membuktikan bahwa aplikasi ADempiere dapat membantu dalam pembuatan faktur pembelian dan penjualan, pengecekan persedian baku secara real time, informasi kebutuhan baku untuk proses produksi (component check), biaya pokok produksi, dan status produksi, sehingga dapat membantu pemilik perusahaan mengambil keputusan lebih cepat.

3. Aplikasi ADempiere dapat menghasilkan laporan secara otomatis tanpa memerlukan biaya lainnya berdasarkan kebutuhan perusahaan. Laporan yang dihasilkan adalah laporan penjualan, laporan persediaan baku, laporan pemakain bahan baku untuk produksi dan laporan keuangan. 
Berdasarkan penelitian ini disarankan untuk penelitian selanjutnya dalam mengimplementasikan ERP terutama dalam menggunakan ADempiere mengembangkan aplikasi ADempiere menambahkan beberapa sub modul pada manufactur management seperti plant manufacturing, MRP, CRP, DRP. Untuk implementasi ERP secara menyeluruh perlu ditambahkan modul human resource dan payroll dan webstore untuk penjualan dan pemesanan produk.

\section{Referensi}

[1] Seo, Goeun. Challenges in implementing enterprise resource planning (ERP) system in large organizations: similarities and differences between corporate and university environment. Diss. Massachusetts Institute of Technology, 2013.

[2] Shaul, Levi, and Doron Tauber. "Critical success factors in enterprise resource planning systems: Review of the last decade." ACM Computing Surveys (CSUR) 45.4. 2013

[3] Handayani, Putu Wuri, and Ultary Hariyaty. "Analisis Fungsionalitas Open Source Software ERP untuk Pengembangan Modul Pembelajaran ERP." Jurnal Sistem Informasi 7.2 (2012): 118-125.

[4] Santosa, Agung Budi., Implementasi ERP langkah demi langkah dengan Adempiere. Batam: Alpha Media, 2010.

[5] Leander, Andre, Adi Wibowo, and Lily Puspa Dewi. "Integrasi Sistem Manajemen Pergudangan dengan Sistem Akuntansi dalam Aplikasi ERP." Jurnal Infra 2.2: pp-133. 2014

[6] Nurcahyo, Yusuf Eko, Purnomo Budi Santosa, and Rudy Soenoko. "Penerapan Enterprise Resource Planning (ERP) Adempiere pada Perusahaan PT Global Agrotek Nusantara (GAN)." 2012

[7] Zaman, Ahmat Khairuz, dkk. 2013. Implementasi System ERP (Enterprise Resources Planning) ADempiere Bagian Produksi Pada PT.X. Jurnal Universitas Trunojoyo Madura - Vol 6.

[8] Khanna, R. B. Production and operations management. PHI Learning Pvt. Ltd., 2015.

[9] Handoko, T.H. 2000. Dasar-dasar Manajemen Produksi dan Operasi. Yogyakarta: BPFE

[10] Rademakers, Tijs. Activiti in Action: Executable business processes in BPMN 2.0. Manning Publications Co., 2012.

[11] Alan, Barbara Haley Wixom, and David Tegarden. Systems analysis and design: An object-oriented approach with UML. John Wiley \& Sons, 2015. 